\title{
An Archaeology of Abundance: Reevaluating the Marginality of California's Islands. KRISTINA M. GILL, MIKAEL FAUVELLE, and JON M. ERLANDSON, editors. 2019. University Press of Florida, Gainesville. xvii + 307 pp. \$100.00 (hardcover), ISBN 978-0-8130-5616-6 - CORRIGENDUM
}

\author{
William R. Hildebrandt
}

Doi: 10.1017/aaq.2019.83, published on behalf of the Society for American Archaeology by Cambridge University Press, September 30, 2019

The original publication of this book review (Hildebrandt 2020) contains a misspelling of the name of the lead author of Chapter 2. The correct spelling is Braje. The sentence should read:

Braje, Erlandson, Gill, Rick, Bentz, and Collins (Chapter 2) deal with the historical degradation and recovery of California's island ecosystems, focusing on how domestic herbi- vores denuded native vegetation, creating a false impression that island terrestrial habitats offered limited economic value.

\section{Reference}

Hildebrandt, William R.

2020 Review of An Archaeology of Abundance: Reevaluating the Marginality of California's Islands, edited by Kristina M. Gill, Mikael Fauvelle, and Jon M. Erlandson. American Antiquity 85:400-401. 